\title{
EFICIÊNCIA DO LODO ATIVADO EM FLUXO CONTÍNUO PARA TRATAMENTO DE ESGOTO
}

\author{
Activated silt efficiency through uninterrupted flow for sewage treatment
}

\author{
Fabiana Dian Ferreira ${ }^{a}$, Márcio Coraiola ${ }^{b}$ \\ a Engenheira Química, Especialista em Gestão dos Recursos Naturais. Curitiba, PR - Brasil, e-mail: fabiana@3r-ambiental.com.br \\ b Engenheiro Florestal, Dr. Prof. Adjunto, Coordenador do Curso de Pós-Graduação em Gestão dos Recursos Naturais, \\ Pontifícia Universidade Católica do Paraná. Curitiba, PR - Brasil, e-mail: marcio.coraiola@pucpr.br
}

\begin{abstract}
Resumo
O tratamento biológico por lodos ativados é atualmente o mais utilizado para a depuração de efluentes sanitários e industriais caracterizados por contaminação de carga orgânica e produtos nitrogenados. Este sistema de tratamento de efluentes é largamente utilizado por se tratar de um sistema com baixo custo de investimento e alta taxa de eficiência. O sistema é composto de um tanque pulmão, para homogeneização das cargas, um tanque de aeração, responsável pela formação dos microorganismos ativos (degradação biológica), um decantador, utilizado para separar os sólidos suspensos do efluente tratado e um tanque de contato para a desinfecção do efluente tratado com o objetivo de remoção das bactérias patogênicas. Neste trabalho está apresentado um estudo de caso de uma estação de tratamento de esgoto projetada para atender 400 pessoas, através do sistema de lodo ativado com aeração convencional e em fluxo contínuo. Foi comprovado, por meio do monitoramento analítico, que o lodo ativado proporciona uma eficiência no tratamento entre 95 e $98 \%$, reduzindo as cargas poluidoras, o que, na maioria das vezes, fornece condições de reaproveitamento da água.
\end{abstract}

Palavras-chave: Lodo ativado; Tratamento biológico; Efluentes.

\begin{abstract}
The biological treatment through activated silt is nowadays the most common employed to chasten the sanitary and industrial waste water characterized by contamination with organic charge and nitrogen products. This waste water treatment is widely employed because it is a low coast system and high efficiency rate on $B O D$ and COD remove. The system is composed of a lung tank, to homogenize the charges, aeration tank, responsible for activate microorganisms formation, responsible for biological degradation through oxygen supply, a decanter, employed to decant solids suspended from the waste water treated and a contact tank used to waste water
\end{abstract}


treated disinfection with the aim to remove the pathogenic bacteria. In this work it is presented a study case of a silt treatment station projected to attend 400 people thought activated silt system with conventional aeration and using continuous flow. It was proved through analytical monitoring that the activated silt afford treatments efficiency between 95 and 98\%, reducing the pollute charge, which, in most cases, provide conditions to water reuse.

Keywords: Activated silt; Biological treatment; Effluents.

\section{INTRODUÇÃO}

Existe hoje uma grande preocupação em relação ao grau de tratamento e ao destino final dos esgotos, as suas conseqüências sobre meio ambiente, a qualidade das águas e aos seus usos e benefícios. Tendo em conta esses aspectos, os estudos, critérios, projetos, relativos ao tratamento e à disposição final dos esgotos, deverão ser precedidos de cuidados especiais que garantam o afastamento adequado dos esgotos e, igualmente, a manutenção e melhoria dos usos e da qualidade dos corpos receptores.

Sistemas biológicos de tratamento trabalham com microorganismos "confinados" em um sistema para degradação da matéria orgânica. Dessa forma, a degradação que ocorreria no corpo receptor acontece dentro de uma unidade projetada especificamente para esse fim. Tais unidades são denominadas reatores biológicos ou biorreatores, uma vez que a remoção (conversão) biológica é realizada por meio de microorganismos, que utilizam a matéria orgânica como alimento (fonte de carbono e energia). A matéria orgânica foi convertida em produtos gasosos ou incorporada como massa microbiana, gerando sólidos.

Os reatores biológicos são projetados de acordo com vários critérios de engenharia, com a finalidade de otimizar as reações de degradação da matéria orgânica das águas residuárias, podendo variar conforme critério do projetista.

Saneamento básico é considerado uma das melhores e mais eficazes soluções para a promoção de saúde no Brasil. Financeiramente, o investimento é relativamente baixo e o retorno é garantido. A promoção da saúde populacional é uma das principais razões da necessidade de se controlar as descargas dos poluentes nos rios e o conseqüente tratamento adequado do esgoto.

Os processos biológicos foram concebidos para serem aplicados na remoção de material orgânico carbonáceo, geralmente medido em termos de Demanda Bioquímica de Oxigênio (DBO5)/ Demanda Química de Oxigênio (DQO), nitrificação, desnitrificação, remoção de fósforo e estabilização do lodo gerado no sistema primário e secundário, possibilitando, assim, a correção das características indesejáveis dos esgotos e sua disposição final, de acordo com as regras e critérios definidos pela legislação ambiental (METCALF, 1991).

O tratamento convencional de esgoto é a combinação de processos físicos e biológicos projetados para remover o material orgânico presente nos despejos. O primeiro método utilizado para tratar esgotos foi a sedimentação com utilização de tanques sépticos, por meio do sistema batizado como Tanques de Imhoff. Esse sistema contava com dois tanques de acumulação que possuíam uma zona de decantação na parte superior e uma zona de digestão na parte inferior (HAMMER; HAMMER Jr., 1996).

Em função da limitada eficiência na sedimentação primária dos esgotos domésticos, foi introduzido o tratamento secundário, que prevê a adição de coagulantes para melhorar a sedimentabilidade do esgoto. Este processo melhorou bastante o tratamento, porém a dosagem de grande quantidade de produtos químicos resultou em altos custos e os substratos orgânicos solúveis não eram removidos. Devido à passagem lenta de esgoto através de uma camada de pedras, o material orgânico era rapidamente decomposto, caracterizando o primeiro ensaio de tratamento de esgotos a nível secundário. Este processo foi chamado de filtro biológico e foi desenvolvido para instalações municipais em 1910 (HAMMER, M. J.; HAMMER Jr., M. J., 1996). 
O segundo maior avanço no tratamento biológico se deu quando foi observado que os sólidos biológicos, desenvolvidos em águas poluídas, floculavam como colóides orgânicos. Essa massa microbiológica, denominada de lodo ativado, rapidamente metabolizava os poluentes da solução e estes podiam ser subsequentemente removidos pela sedimentação por gravidade.

A primeira Estação de Tratamento de Esgotos (ETE) foi a de Salford (Inglaterra) com capacidade para tratar 303 m3/dia. Em 1916, foi inaugurada, nos Estados Unidos, a ETE San Marcos, localizada no Texas, com capacidade para tratar $454 \mathrm{~m} 3 /$ dia; dez anos depois, em 1927, a ETE de Chicago North, também nos Estados Unidos, consagra o processo de lodos ativados tratando 7,5 m3/ s (JORDÃO, 1998).

Neste trabalho, o objetivo principal é avaliar o processo de tratamento biológico do tipo lodo ativado, em estações de tratamento de esgoto e comprovar a sua eficiência. Foi avaliada uma estação de tratamento de esgoto projetada para atender 400 pessoas por meio do sistema de lodo ativado com aeração convencional e em fluxo contínuo.

\section{MATERIAL E MÉTODOS}

\section{Características gerais do tratamento aeróbio por lodo ativado}

O principio geral deste processo é acelerar a oxidação e decomposição natural da matéria orgânica, o mesmo que acontece nos corpos d'água (matéria orgânica é parte convertida em CO2 e $\mathrm{H} 2 \mathrm{O}$ ). A biomassa bacteriana pode ser separada do despejo tratado por simples decantação (SPERLING, 1996). A distinção entre os processos é verificada somente por meio de algumas variáveis, tais como o tempo de retenção celular e fator alimento/microrganismo. Para o sistema convencional de lodos ativados os seguintes valores são apresentados:

- Tempo de retenção celular:

- Entre 4 e 10 dias (SPERLING, 1996)

- Entre 5 e 15 dias (METCALF, 1991; QASIM, 1985)

- Relação alimento/microrganismo:

- Entre 0,2 e 0,4 kg DBO5 aplicada / kg Sólidos Voláteis / dia, para fluxo pistão (METCALF, 1991; QASIM, 1985)

- Entre 0,2 e 0,6 kg DBO5 aplicada / kg Sólidos Voláteis / dia, para sistemas completamente misturados (METCALF, 1991; QASIM, 1985)

- Entre 0,3 e 0,8 kg DBO5 aplicada / kg Sólidos Voláteis / dia (SPERLING, 1996)

- Tempo de detenção hidráulica:

- Entre 6 e 8 horas (SPERLING, 1996)

- Entre 4 e 8 horas para sistemas de fluxo pistão (METCALF, 1991; QASIM, 1985)

- Entre 3 e 5 horas para sistemas completamente misturados (METCALF, 1991; QASIM, 1985)

Nestas condições, a biomassa retirada do sistema contém grande quantidade de matéria orgânica, necessitando de uma etapa posterior para estabilização. Os sistemas de lodos ativados convencionais necessitam, ainda, de uma etapa preliminar de tratamento, o decantador primário, que é utilizado para remover os sólidos sedimentáveis dos esgotos, reduzindo, assim, a carga orgânica que irá para os tanques de aeração. 


\section{Substâncias orgânicas nos esgotos}

O substrato orgânico nos esgotos é a fonte de energia para os microrganismos e são divididos em três grandes categorias: proteínas $(40-60 \%)$, carboidratos $(25-50 \%)$ e gorduras $(10 \%)$ (HAMMER; HAMMER Jr, 1996; METCALF, 1991). Além dessas substâncias, encontram-se nos esgotos pequenas quantidades de moléculas sintéticas orgânicas, compreendendo desde as estruturas mais simples até as mais complexas. Nos últimos anos, a presença dessas substâncias tem complicado o sistema de tratamento de esgotos, pois muitos desses compostos não podem ser decompostos biologicamente ou apresentam uma lenta decomposição. Para um esgoto de concentração média, aproximadamente $75 \%$ dos sólidos suspensos e $40 \%$ dos sólidos filtráveis são de natureza orgânica.

A maioria dos carboidratos, proteínas e gorduras presentes nos esgotos estão na forma de grandes moléculas, que não podem penetrar na membrana celular dos microrganismos. O primeiro passo para a decomposição do composto orgânico pelas bactérias é a hidrólise dos carboidratos em açúcar solúvel, das proteínas em aminoácidos e gorduras em ácidos graxos de cadeia curta. $\mathrm{Na}$ degradação aeróbia, o composto orgânico é convertido em gás carbônico e água, enquanto que na digestão anaeróbia, os produtos finais são ácidos orgânicos, álcoois, gás carbônico, metano e gás sulfídrico.

De toda a matéria orgânica presente nos esgotos, $60 \%$ a $80 \%$ é rapidamente assimilada por meio da biodegradação. Muitos compostos orgânicos como a celulose, hidrocarbonetos de cadeia saturada longa e outros compostos complexos são considerados não biodegradáveis, pois necessitam de um tempo muito longo para serem assimilados. Derivados de petróleo, detergentes, pesticidas e outros compostos orgânicos sintéticos, também são resistentes a biodegradação, e alguns são tóxicos e inibem a atividade dos microrganismos nos processos de tratamento biológico.

Os microrganismos realizam a decomposição da matéria orgânica através de enzimas, que agem como catalisadores e podem atuar externamente (extracelular) e ou internamente (intracelular). A ação das enzimas são afetadas pelas condições ambientais como $\mathrm{pH}$, temperatura e concentração do substrato (QASIM, 1985).

\section{Monitoramento: DBO5 e DQO}

A demanda química de oxigênio é frequentemente utilizada para caracterizar os despejos domésticos e/ou industriais. Para realizar o teste adiciona-se uma quantidade conhecida de solução padrão de dicromato de potássio, ácido sulfúrico contendo sulfato de prata (catalisador) e uma quantidade de amostra em um frasco. Esta mistura é refluída durante 2 horas, sendo que a maior parte do material orgânico é destruída no aquecimento dessa mistura de cromo e ácido sulfúrico. Após a mistura esfriar, o dicromato remanescente é titulado com uma solução padrão de sulfato ferroso amoniacal, usando ferro como indicador. $\mathrm{O}$ íon ferroso reage com o íon dicromato, mudando da cor azulesverdeado para vermelho tijolo, indicando o final da titulação.

A maioria dos compostos orgânicos oxida entre 95 a 100\%. O interferente mais comum para o teste da DQO é o íon cloreto, pois precipita a prata e, consequentemente, tira o poder catalítico dela. Isso interfere na determinação, pois compostos alifáticos de cadeia longa são oxidados mais eficientemente na presença do sulfato de prata, que atua como catalisador. As amostras para análises de DQO podem ser coletadas em frascos de plástico ou vidro e são conservadas durante 07 dias, quando preservadas com ácido sulfúrico para $\mathrm{pH}<2$ e refrigeradas a $4^{\circ} \mathrm{C}$ (CLESCERI, L. S.; GREENBERG, A. E.; EATON, A. D., 1998).

A demanda bioquímica de oxigênio (DBO5) é o parâmetro mais comum para definir a força dos esgotos domésticos e industriais. A DBO5, por definição, é a quantidade de oxigênio utilizada por uma população mista de microrganismos na oxidação aeróbia na temperatura de $20^{\circ} \mathrm{C} \pm 1^{\circ} \mathrm{C}$.

$\mathrm{O}$ teste consiste em se diluir uma quantidade conhecida de esgoto com água preparada e colocá-la em frascos de $300 \mathrm{ml}$. A água de diluição, contendo solução tampão de fosfatos, sulfato de magnésio, cloreto de cálcio e cloreto férrico é saturada com oxigênio dissolvido. O esgoto é a fonte de carbono para os microrganismos e a água de diluição fornece os nutrientes e o oxigênio necessário. A primeira reação é a metabolização do substrato orgânico o que causa um consumo de oxigênio pelas bactérias, liberando gás carbônico e aumentando a população das bactérias. A segunda reação é o 
resultado da utilização do oxigênio pelos protozoários que se alimentam das bactérias. A depleção de oxigênio dos frascos de incubação é diretamente relacionada com a quantidade de substrato orgânico biodegradável presente na amostra.

A demanda bioquímica de oxigênio dos esgotos, na realidade, não é um valor único, pois depende do tempo. A oxidação bioquímica é um processo lento e teoricamente leva um tempo infinito para se completar. Dentro de um período de 20 dias, a oxidação do material orgânico é de 95 a 99\%, em 5 dias a oxidação do material orgânico gira em torno de 60 a 70\% (HAMMER; HAMMER Jr, 1996; METCALF, 1991).

Para amostras de efluentes de estações de tratamento de esgotos a nitrificação poderá ocorrer antes do período padrão de incubação de 5 dias, pois essas amostras podem conter uma alta população de bactérias nitrificantes (HAMMER; HAMMER Jr, 1996). Para prevenir a nitrificação adiciona-se $10 \mathrm{mg} /$ 1 de 2-cloro-6(tricloro metil)piridina na água de diluição (CLESCERI; GREENBERG; EATON, 1998).

\section{DESCRITIVO DAS UNIDADES INTEGRANTES DO SISTEMA DE TRATAMENTO}

\section{Estação de tratamento}

Neste sistema, o esgoto bruto segue para um tanque de aeração, com injeção de oxigênio por difusores de ar, acelerando a atividade biológica de degradação por meio de bactérias aeróbicas. A remoção dos poluentes presentes é acima de 95\%. As bactérias presentes formam uma biomassa denominada lodo, totalmente em suspensão, que foi separada na unidade seguinte que é o decantador. Esse lodo é recirculado para o tanque de aeração e o excedente é descartado para os leitos de secagem. O esgoto tratado passa pelo tanque de contato onde é realizada uma desinfecção e seguindo para corpo receptor (Figura 1).

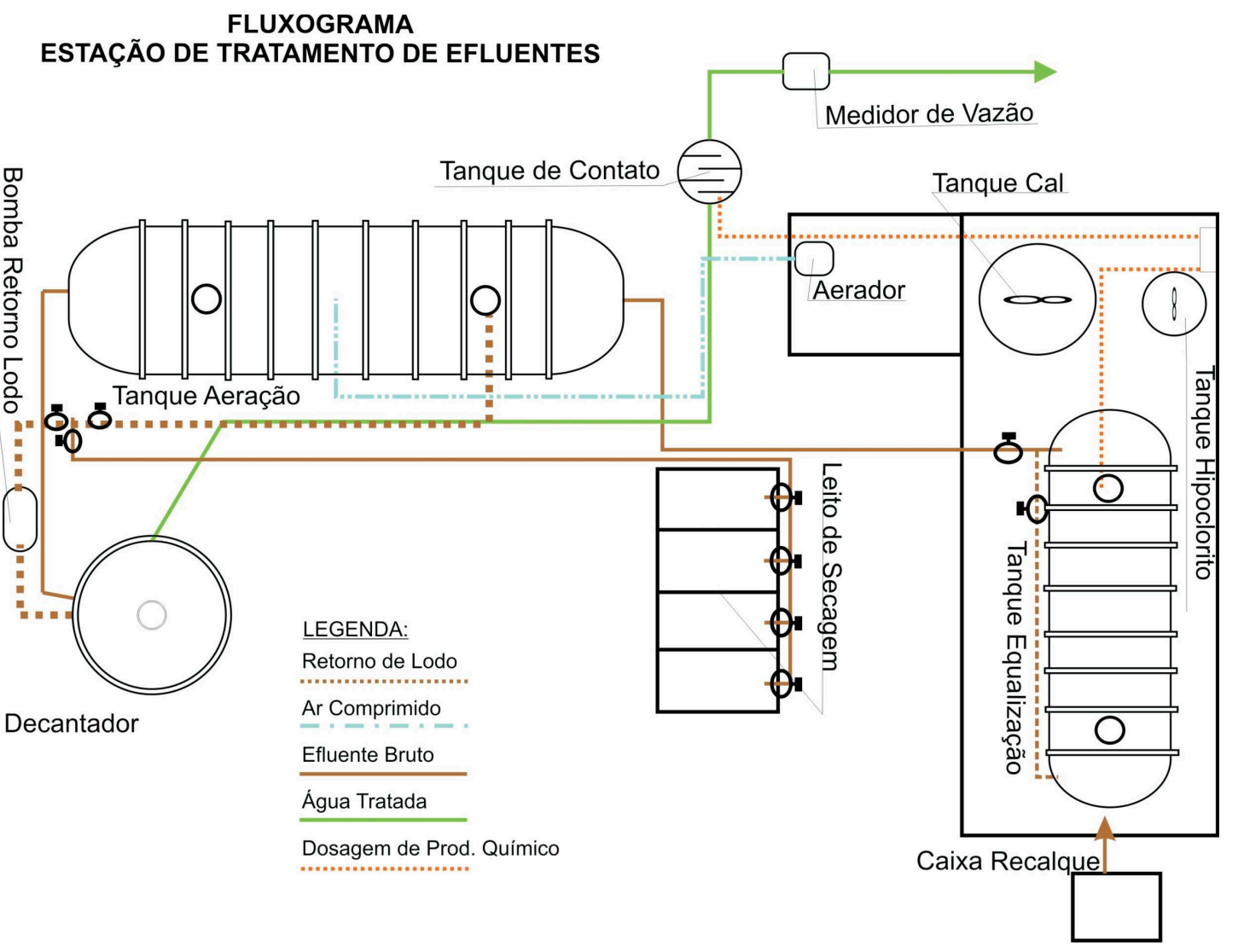

FIGURA 1 - Fluxograma do funcionamento de uma estação de tratamentos de efluentes Figure 1 - Flowchart of the operation effluent treatment station 


\section{Caixa de gordura}

Unidade utilizada apenas no refeitório, responsável pela quebra de emulsão da gordura e retenção dela, reduzindo-a em média de $80 \%$, e contribuindo para um tratamento biológico mais eficiente. Foi apenas uma unidade, encaminhando em seguida o efluente à ETE sanitária (Figura 2).
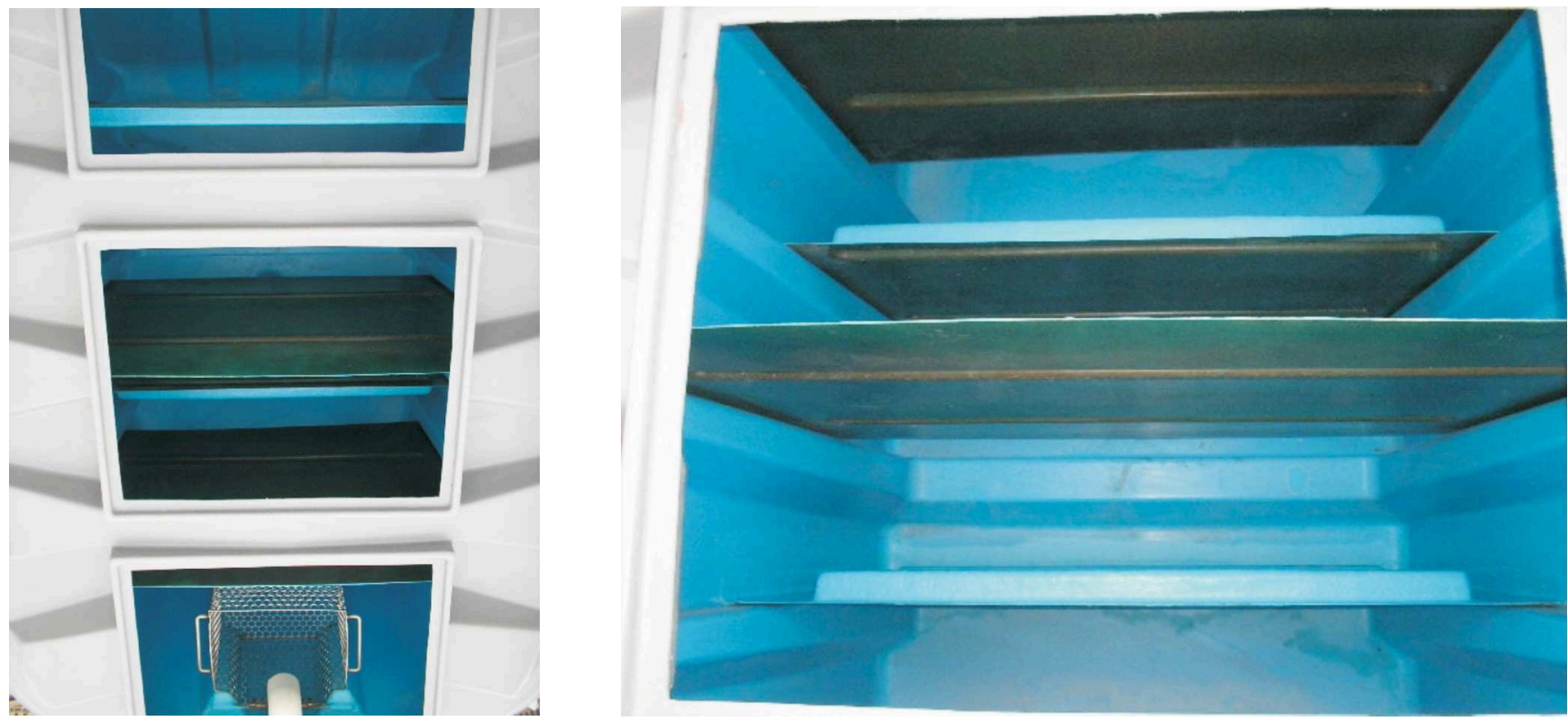

FIGURA 2 - Compartimentos da caixa de gordura

Figure 2 - Box of fat compartments

\section{Tanque Pulmão}

Esta unidade deverá estar implantada ao lado do Tanque de Aeração, recebendo os efluentes do refeitório e dos sanitários. Após a homogeneização seguem ao Tanque de Aeração Biológica. Sua função, portanto, é de regularizar as cargas, já que a vazão diária é baixa, podendo ser regularizada em um curto perido, durante o dia (Figura 3).

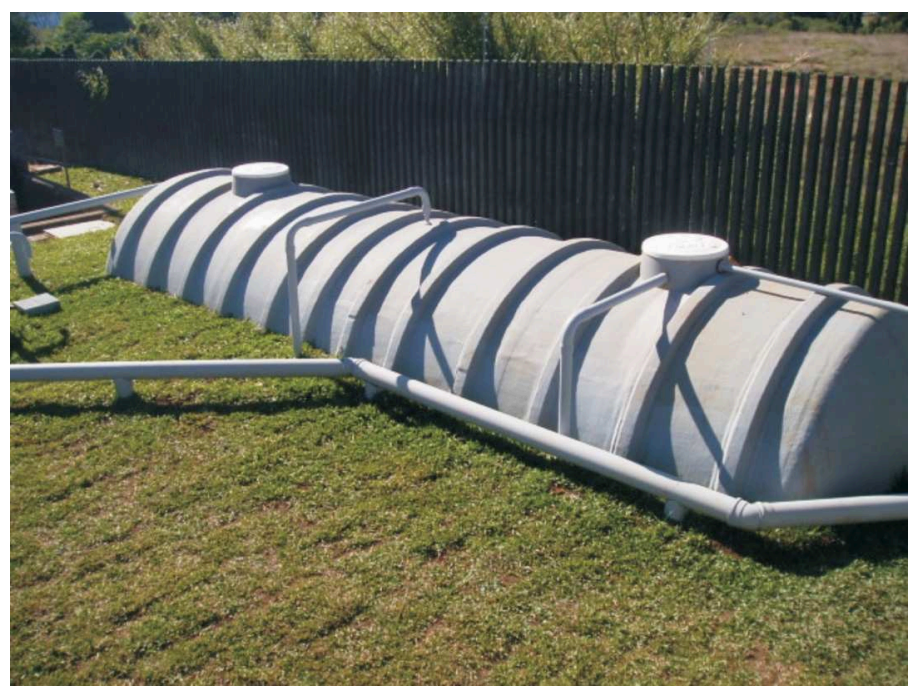

FIGURA 3 - Tanque Pulmão

Figure 3 - Lung tank 


\section{Tanque de Aeração (TA)}

Esta unidade é responsável pela formação dos microorganismos ativos (Figura 4). É o local onde são fornecidas as condições ideais para que os microorganismos responsáveis pela degradação biológica se desenvolvam e cumpram sua função de remover a matéria orgânica. É fornecido oxigênio e micro/macro nutrientes que já estarão disponíveis no próprio esgoto, uma vez que a urina apresenta uma grande quantidade de nitrogênio, e o fósforo está muito presente nos detergentes utilizados. É importante um controle anual destes parâmetros.

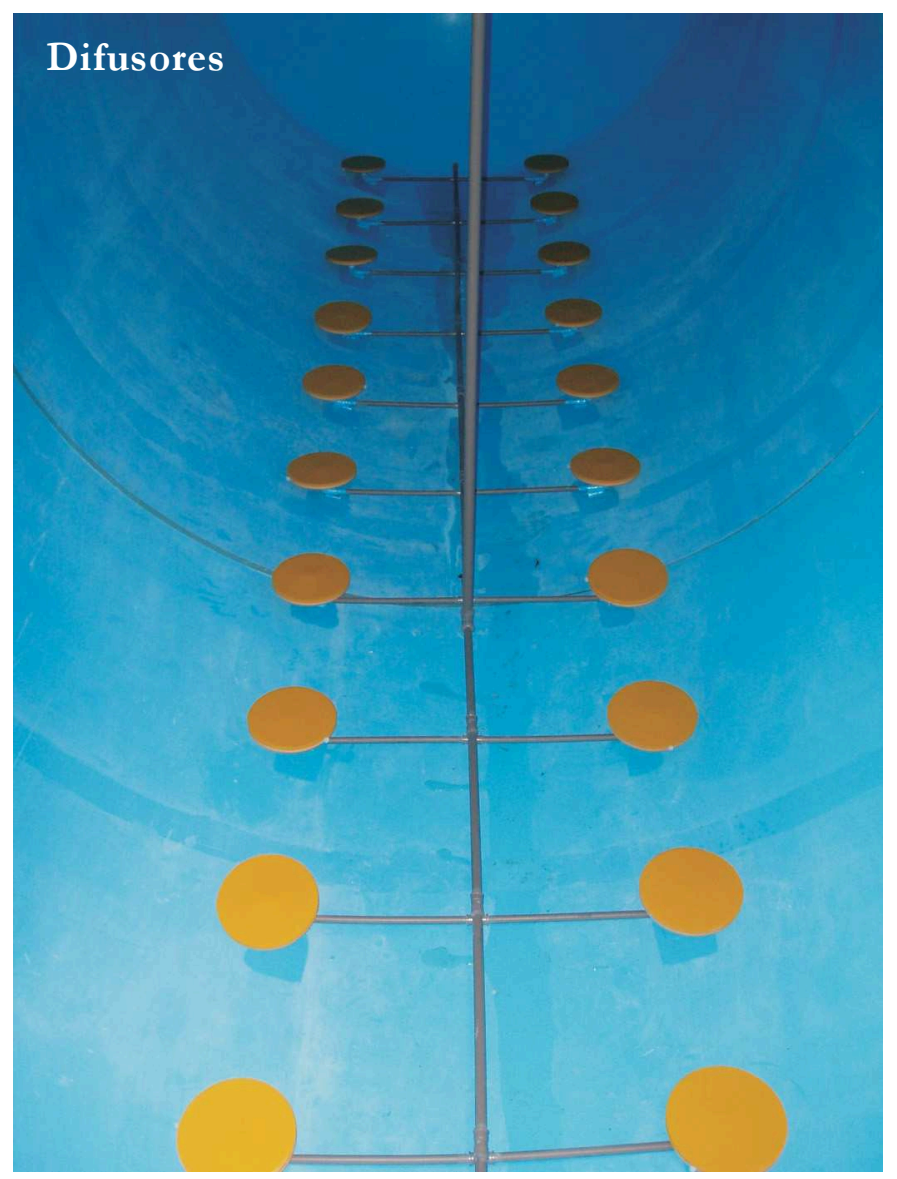

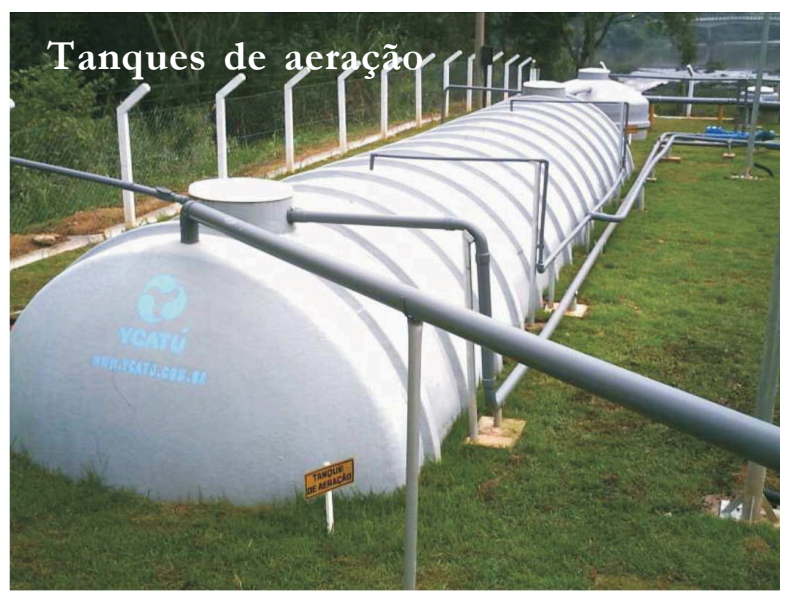

FIGURA 4 - Tanques de aeração e difusores Figure 4 - Aeration tanks diffusers

\section{Decantador}

O decantador é empregado para separar os sólidos suspensos do efluente tratado, que são formados pelos microorganismos ativos (Tanque de Aeração) e dos inativos (Figura 5). Portanto, com sua sedimentação eles retornam ao Tanque Aerado e o clarificado segue, superficialmente, ao destino final. O método utilizado para efetuar a reciclagem do lodo é feito por pressão hidráulica e o designer de sua estrutura interna permite este retorno. Uma vez que ele opera como mistura completa, a homogeneidade da massa líquida ocorre rapidamente, não prejudicando as bactérias, pois elas estarão em constante aeração. Com as variações nas condições do meio, podem ocorrer oscilações comportamentais na precipitação, razão pela qual devem estar previstas reservas de biomassa para suprir perdas ocasionais. 


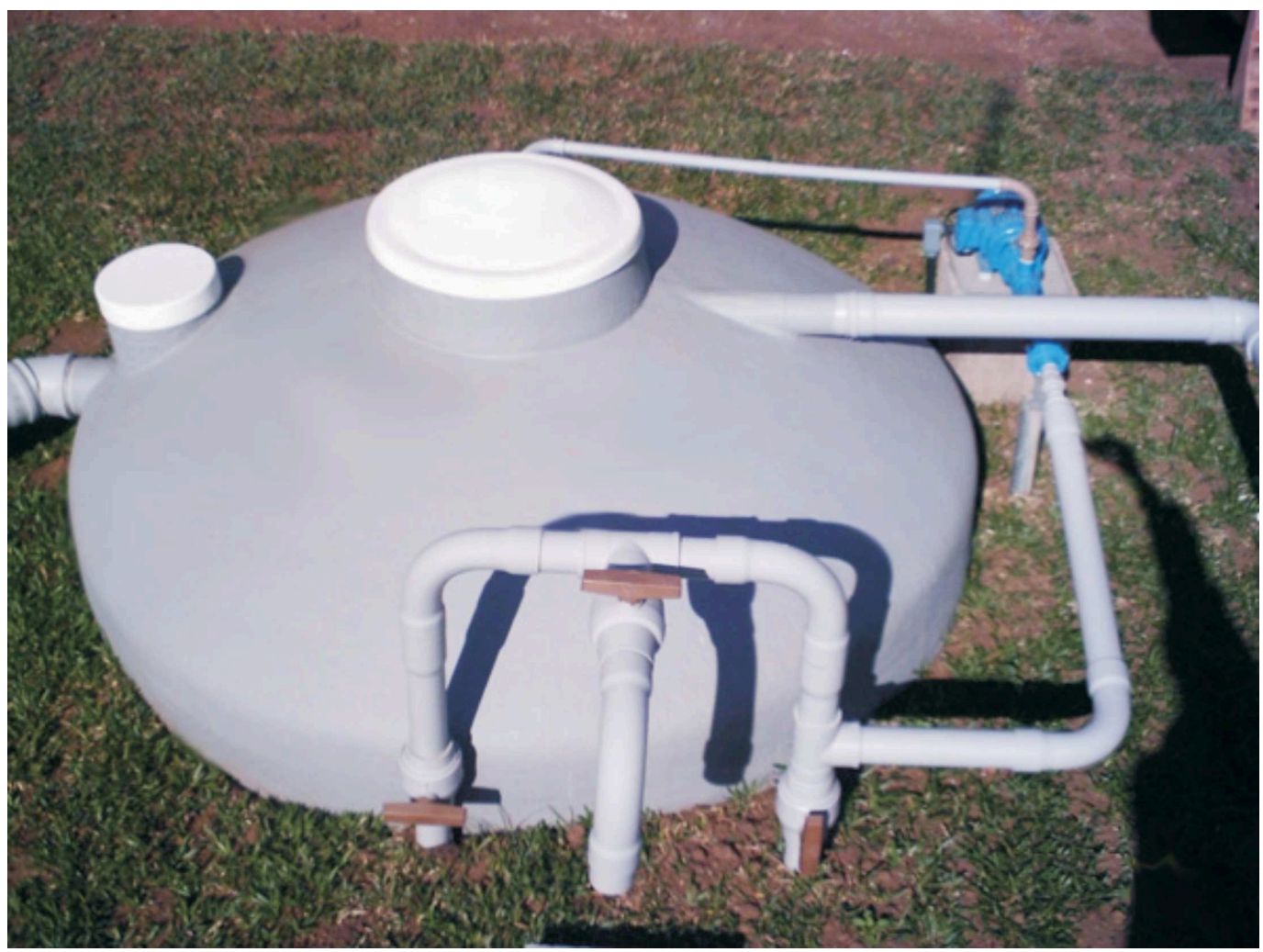

FIGURA 5 - Decantador

Figure 5 - Decanter

\section{Leito de secagem}

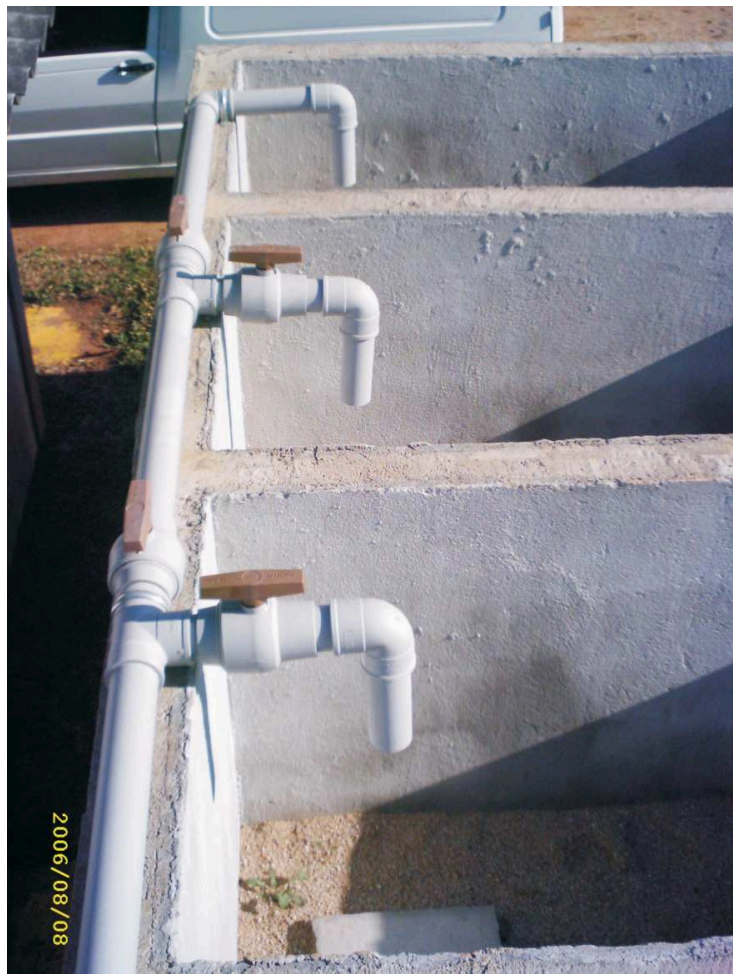

Em estações com vazões baixas, a desidratação do lodo tem sido feita nos leitos de secagem, face à maior simplicidade desse processo quando comparado com os processos mecanizados (VIESSMAN Jr.; HAMMER, 1985). O leito de secagem de lodo é construído em alvenaria, com 3 camadas de brita e areia, afim de que o efluente seja filtrado e o lodo fique na camada externa, perdendo boa parte da umidade e facilitando posterior remoção. Toda a água retirada através desta filtração retorna ao tanque pulmão (Figura 6).

FIGURA 6 - Leito de Secagem

Figure 6 - Drying bed 


\section{Desinfecção}

A desinfecção é a etapa final do tratamento e tem como objetivo principal a remoção de bactérias patogênicas, fornecendo condições de reaproveitamento e/ou lançamento com teor mínimo de bactérias, não impactante no corpo receptor (Figura 7).

\section{Medidor de vazão}

Esta etapa se caracteriza pela medição do volume de lançamento, sendo adicionado após a última etapa de tratamento (Medidor Thompson). Esse equipamento é instalado na saída do efluente final e efetua a leitura por meio da visualização da régua instalada na parte interna do medidor, mostrando a leitura direta em metros cúbicos por hora (m3/h) (Figura 8).

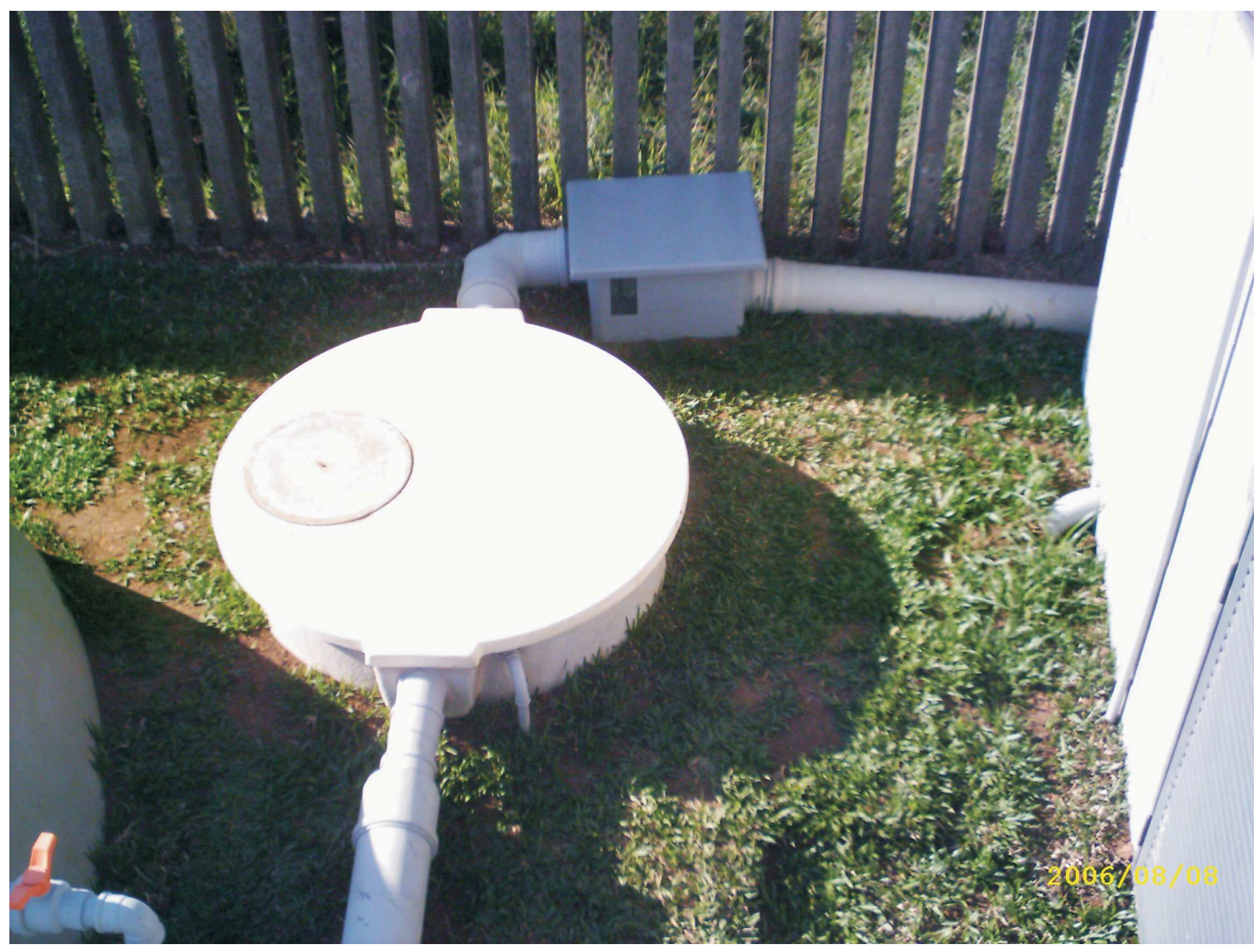

FIGURA 7 - Tanque de Contato

Figure 7 - Contact tank 

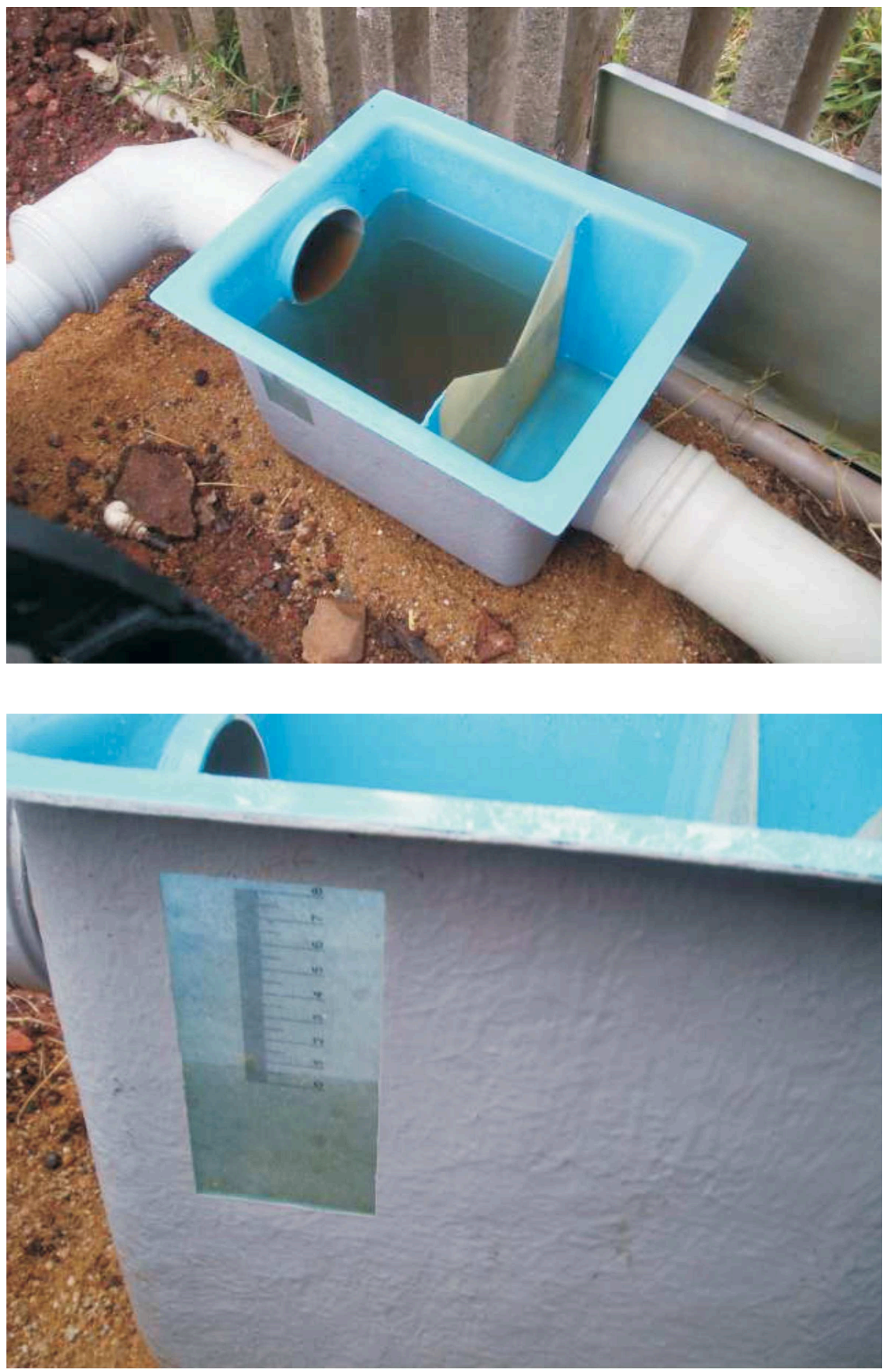

FIGURA 8 - Medidor Thompson

Figure 8 - Thompson meter 
O método do vertedor utiliza um dispositivo, introduzido perpendicularmente às linhas do fluxo de líquido, que possui abertura por onde passa o fluxo. A vazão deve ser determinada a partir da leitura efetuada no vertedor (Tabela 1).

TABELA 1 - Cálculo da vazão em vertedouro triangular

Table 1 - Flowing out calculation in triangular spillway

\begin{tabular}{cc}
\hline $\mathbf{H}$ (cm) & $\mathbf{Q}(\mathbf{m} \mathbf{3} / \mathbf{h})$ \\
\hline 4 & 1,44 \\
5 & 2,88 \\
6 & 4,32 \\
7 & 6,48 \\
8 & 9 \\
\hline
\end{tabular}

Fonte: NBR - 13403

\section{Principais parâmetros de controle}

Antes de iniciar a operação é indispensável o conhecimento básico de alguns parâmetros utilizados na manutenção e controle da Estação de Tratamento de Efluentes (sistema biológico por Lodos Ativados) (PESSOA, 1995).

\section{Oxigênio dissolvido}

O sistema de aeração adotado no Tanque de Aeração ou Reator Biológico conta com sistema de ar difuso, com difusores submersos no líquido e tubulações distribuidoras de ar. $\mathrm{O}$ ar é introduzido próximo ao fundo do reator biológico para evitar a sedimentação do lodo e fornecer o oxigênio necessário para a sobrevivência dos microorganismos. Este controle é importante, pois indica a quantidade de oxigênio no Tanque de Aeração, de modo que os microrganismos possam estar realizando seguramente sua tarefa e, ainda, apresentando um superávit no meio.

O lodo ativado trabalha com uma faixa larga de Oxigênio Dissolvido, porém, normalmente, se procura obter um intervalo de 3,0-5,0 mg O2 / L. Valores abaixo destes podem causar diversos problemas entre eles a perda de massa biológica com a morte de microorganismos e, consequentemente, odores desagradáveis. Valores acima desses podem provocar sérios desequilíbrios ao processo, como por exemplo, a baixa decantabilidadde do lodo (PESSOA, 1995).

\section{Sólidos suspensos}

No interior do tanque de aeração temos uma quantidade de sólidos suspensos sob a forma de flocos de lodo ativado. Teremos sólidos suspensos totais (SST), sólidos suspensos voláteis (SSV) e sólidos suspensos fixos ou inorgânicos (SSF ou SSI). O SSV poderá estar na faixa de 2.000 - 4.000 $\mathrm{mg} / 1$ (PESSOA, 1995).

\section{Índice de lodo - sólidos sedimentáveis}

O índice de lodo - sólidos sedimentáveis deve, preferencialmente, encontrar-se na faixa de $300-400 \mathrm{ml} / 1$ (esgoto sanitário), o que contribui na boa sedimentabilidade do lodo e conseqüente aumento na remoção de sólidos do clarificado (Figura 9). 


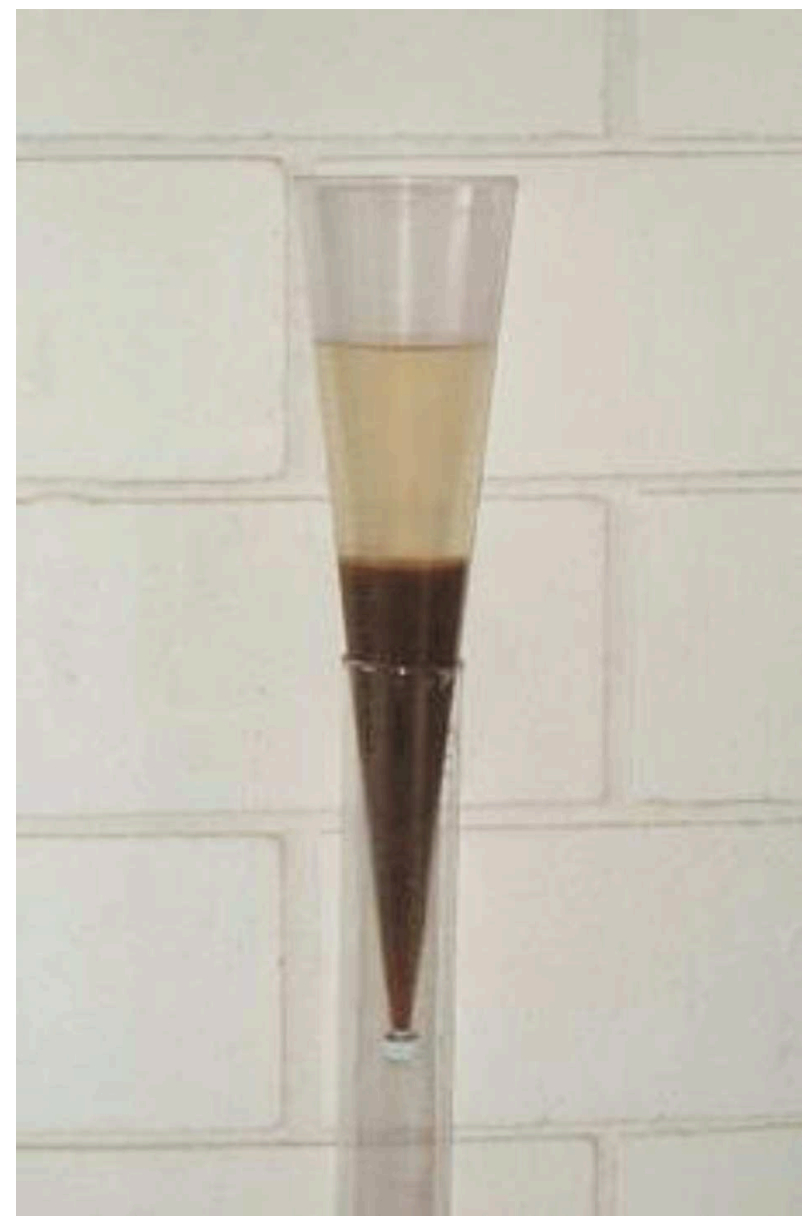

FIGURA 9 - Cone de Sedimentação IMHOFF

Figure 9 - IMHOFF Sedimentation cone

\section{Demanda Bioquímica de Oxigênio - $\mathrm{DBO}_{5,20^{\circ} \mathrm{C}}$}

É a quantidade de oxigênio necessária para oxidação bioquímica de substancias orgânicas presentes na amostra (efluente), expressa em mg O2/L. Os organismos vivos dependem de oxigênio para produzir energia necessária a manter suas funções metabólicas, crescimento e reprodução. Os organismos aeróbios necessitam de $\mathrm{O} 2$ livre para a mineralização da matéria orgânica, resultando destas reações compostos inorgânicos simples como $\mathrm{CO} 2, \mathrm{H} 2 \mathrm{O}$ e $\mathrm{NH}$. A quantidade de matéria orgânica presente, indicada pela determinação da $\mathrm{DBO}$, é importante para se conhecer o grau de poluição de uma água residuária, para se dimensionar as estações de tratamento de esgotos e medir a sua eficiência (PESSOA, 1995).

\section{Demanda química de oxigênio - DQO}

A DQO é a quantidade de oxigênio necessário para a oxidação da matéria orgânica e parte de compostos inorgânicos como $\mathrm{Fe}, \mathrm{Mn}, \mathrm{SO}$, etc. Ela corresponde a uma oxidação química da matéria orgânica, obtida por meio de um forte oxidante em meio ácido (PESSOA, 1995). 


\section{Metodologia para avaliação do tratamento}

Nesta etapa são descritos os métodos utilizados para a realização do monitoramento, as formas de tratamento e os parâmetros analíticos a serem avaliados.

Procedimentos de coleta e preservação das amostras

As análises foram terceirizadas, portanto a responsabilidade pela metodologia de coleta ficou a cargo do laboratório LIMNOBRÁS.

\section{Caracterização do esgoto}

A caracterização do esgoto foi verificada mediante as análises dos parâmetros descritos a seguir:

- Caracterização físico-química e biológica

No Quadro 1 estão apresentados os principais parâmetros que foram controlados e avaliados na caracterização da composição do esgoto e tratamento.

QUADRO 1 - Parâmetros gerais de controle

Chart 1 - General control parameters

\begin{tabular}{|c|c|c|c|c|}
\hline \multirow[t]{2}{*}{ Local } & \multirow{2}{*}{ Ponto de Coleta } & \multirow{2}{*}{ Parâmetro } & \multicolumn{2}{|c|}{ AMOSTRA } \\
\hline & & & Uso & Frequência \\
\hline \multirow{8}{*}{ 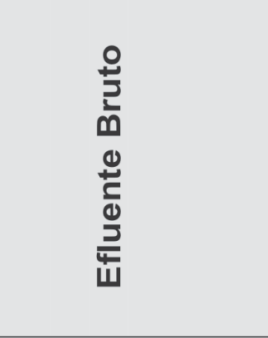 } & \multirow{8}{*}{ Tanque Pulmão } & $\mathrm{pH}$ & $\mathrm{CP}$ & Diária \\
\hline & & $\mathrm{DBO}_{5,20^{\circ} \mathrm{C}}$ & $A D$ & Mensal \\
\hline & & DQO & $A D$ & Mensal \\
\hline & & Sol. Sed. & $\mathrm{CP}$ & Diária \\
\hline & & O.G minerais & $A D$ & Mensal \\
\hline & & $\mathrm{O} . \mathrm{G}$ vegetais & $A D$ & Mensal \\
\hline & & Nitrogênio Amoniacal & $\mathrm{CP}$ & Mensal \\
\hline & & Fósforo Total & $\mathrm{CP}$ & Mensal \\
\hline \multirow{5}{*}{ 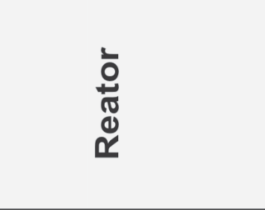 } & \multirow{5}{*}{ Reator } & SSV & $\mathrm{CP}$ & Mensal \\
\hline & & SST & $\mathrm{CP}$ & Mensal \\
\hline & & O.D & $\mathrm{CP}$ & Diária \\
\hline & & $\mathrm{pH}$ & $\mathrm{CP}$ & Diária \\
\hline & & Sol. Sedimentáveis & $\mathrm{CP}$ & Diária \\
\hline \multirow[t]{2}{*}{ Lodo de retorno } & \multirow{2}{*}{$\begin{array}{l}\text { Recalque } \\
\text { (Boca 1)T.A }\end{array}$} & SSV & $\mathrm{CP}$ & Mensal \\
\hline & & SST & $\mathrm{CP}$ & Mensal \\
\hline \multirow{9}{*}{ 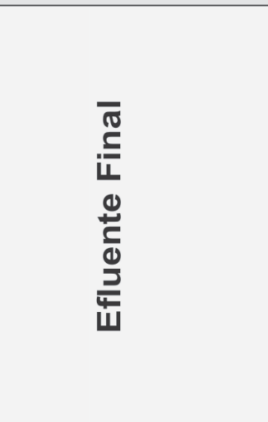 } & \multirow{9}{*}{$\begin{array}{l}\text { Tanque Contato } \\
\text { (Última célula) }\end{array}$} & $\mathrm{pH}$ & $\mathrm{CP}$ & Diária \\
\hline & & $\mathrm{DBO}_{5,20^{\circ} \mathrm{C}}$ & $A D$ & Mensal \\
\hline & & DQO & $A D$ & Mensal \\
\hline & & Sol. Sed. & $\mathrm{CP}$ & Diária \\
\hline & & O.G minerais & $A D$ & Mensal \\
\hline & & O.G vegetais & AD & Mensal \\
\hline & & Nitrogênio Amoniacal & СР & Mensal \\
\hline & & Fósforo Total & CP & Mensal \\
\hline & & $\begin{array}{l}\text { Ecotoxicidade } \\
\text { (Daphina Magna) }\end{array}$ & $A D$ & Trimestral \\
\hline
\end{tabular}




\section{Unidades de tratamento}

A pesquisa foi realizada numa unidade de tratamento projetada para atender 400 pessoas, localizada em Curitiba (Figura 10). Os esgotos sanitários provenientes dos banheiros e do refeitório são encaminhados ao sistema de tratamento composto de lodo ativado e desinfecção. Os esgotos dos banheiros e refeitório são direcionados a um tanque pulmão para então seguirem ao tratamento biológico. No entanto, antes de entrarem no tanque pulmão, eles devem passar por tanques retentores de seus respectivos sólidos. Assim, o esgoto dos banheiros passa, primeiramente, por uma fossa e o esgoto do refeitório passa por uma caixa de gordura. Foram também regularizadas as cargas poluentes e pH.

O efluente homogeneizado é bombeado ao tratamento biológico aerado do tipo lodo ativado, o qual passará, em seguida, por um sistema de decantação, para separar os sólidos gerados e, finalmente, por desinfecção química. Cumpre ressaltar que os efluentes do refeitório deverão passar por um sistema de peneiramento antes de entrarem na caixa removedora de gordura, promovendo uma melhor eficiência desta unidade. O lodo ativado projetado é do tipo convencional, em tamanho compacto, com aeração por ar difuso.

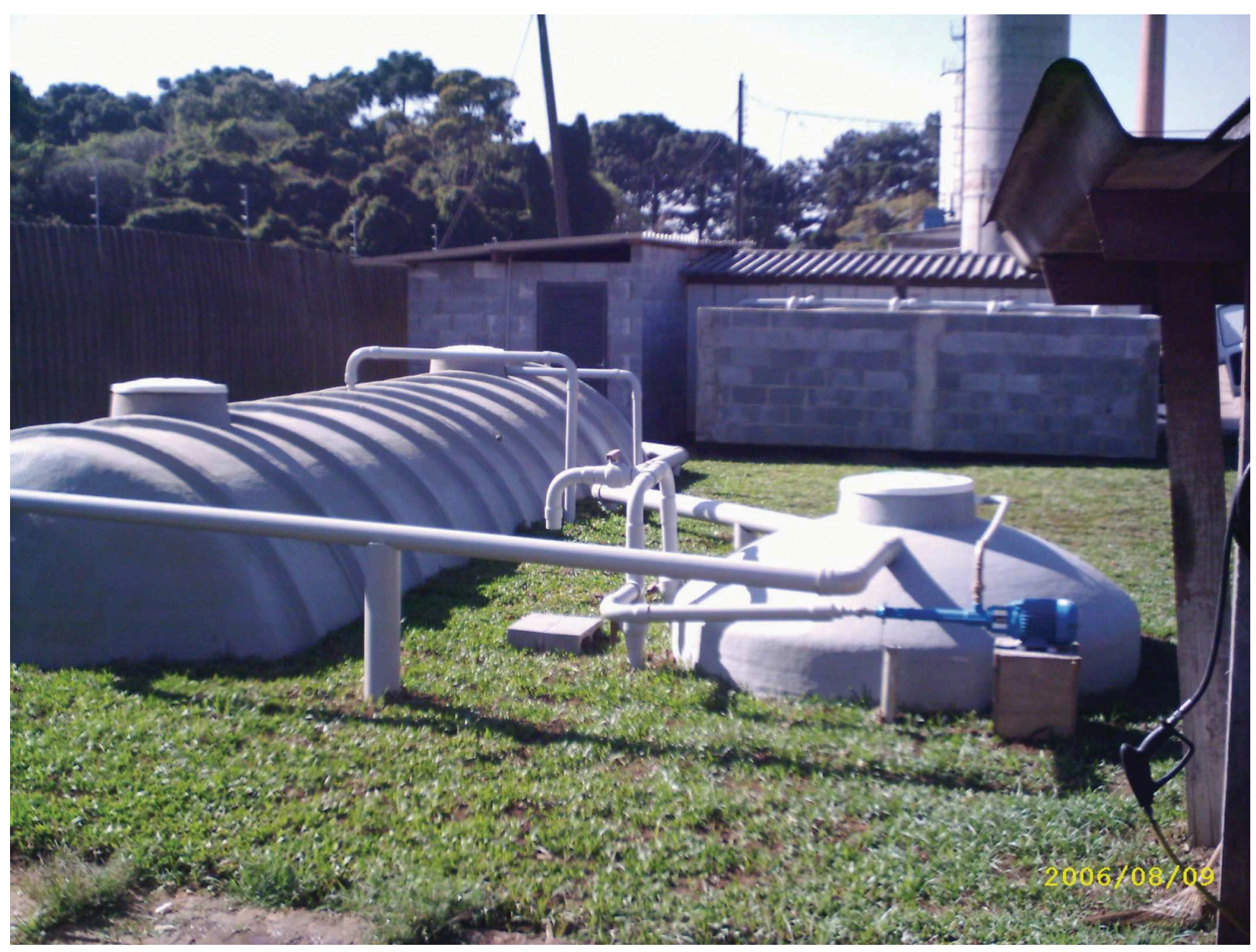

FIGURA 10 - Vista geral da Estação de Tratamento de Esgoto (ETE)

Figure 10 - Overview of the treatment station 
Lodo ativado com tanque de aeração e decantador secundário

O reciclo de lodo é contínuo, com bomba ligada 24 horas/dia. O reator é alimentado continuamente, avaliando o pH de entrada do esgoto bruto e a formação da massa biológica no interior do tanque, mediante análises de sólidos sedimentáveis e oxigênio dissolvido (Figura 11). As análises laboratoriais complementarão, com maior segurança, a avaliação destes parâmetros e, também, dos sólidos suspensos e parâmetros de controle de eficiência do esgoto de entrada e saída final.

Os principais parâmetros avaliados foram:

- F/M - fração alimento/microorganismos;

- Tempo de retenção (d);

- Massa de sólidos suspensos voláteis formados no Tanque de aeração (SSVTA);

- Idade do lodo $(\theta)$;

- Avaliação do reciclo de lodo, entre outros.

As análises físico-químicas e biológicas foram realizadas no laboratório da LIMNOBRÁS.

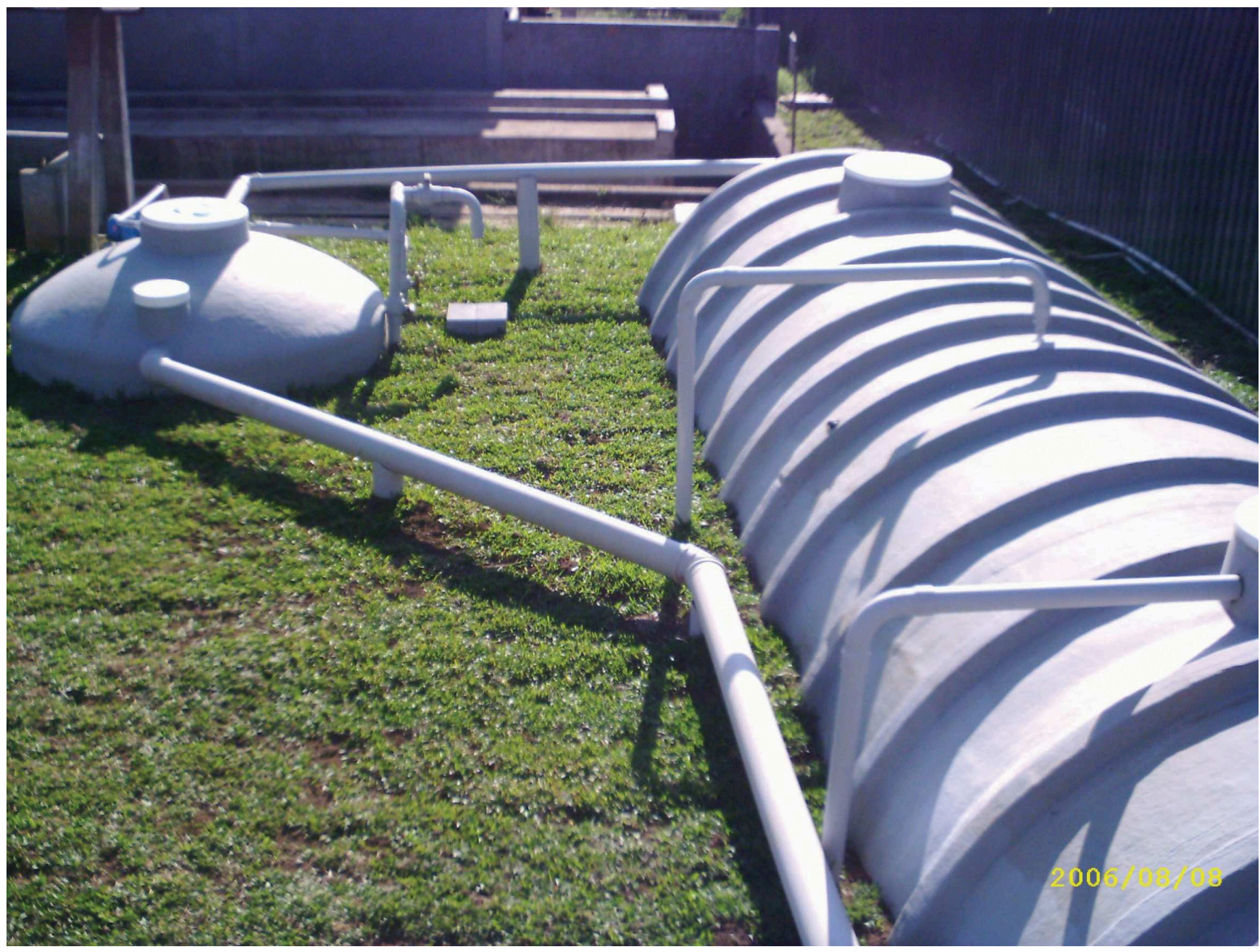

FIGURA 11 - Decantador e tanque de sedimentação

Figure 11 - Decanter and sedimentation tank 


\section{Parâmetros de controle do lodo ativado}

- Relação F/M

A relação F/M foi calculada com a seguinte fórmula (SPERLING, 1997):

$$
\frac{F}{\mathrm{M}}=\frac{Q \cdot D B O}{V \cdot S S V T A}
$$

Onde:

$\mathrm{F} / \mathrm{M}=$ razão alimento/microorganismo, g de DBO5 por dia, por g SSVTA

$\mathrm{Q}=$ vazão de esgoto, $\mathrm{m}^{3} / \mathrm{d}$

$\mathrm{DBO}_{5}=\mathrm{DBO}_{5}$ do efluente

$\mathrm{V}=$ volume do tanque de aeração, $\mathrm{m}^{3}$

SSVTA = sólidos suspensos voláteis, $\mathrm{mg} / 1$

A razão F/M se relaciona com o estado metabólico do sistema biológico. Os valores desses parâmetros situam-se na faixa de 0,05 a 1,5 e, relacionados diretamente a esse parâmetro, estão as determinações da forma de introdução de oxigênio, o volume do tanque de aeração, o volume do lodo descartado e a eficiência do processo.

- $\quad$ Idade do lodo

Refere-se ao tempo médio que os microorganismos permanecem no processo de tratamento (tempo médio de retenção celular). Pode ser calculado pela fórmula (SPERLING, 1997):

$$
\theta=\frac{\mathrm{kg} / \mathrm{dia} \text { SSVTA }+\mathrm{kg} / \mathrm{dia} \text { SSV DS }}{\mathrm{kg} \mathrm{SSV} / \text { dia no lodo em excesso }+\mathrm{kg} \mathrm{SSV} / \text { dia no efluente tratado }}
$$

Outra forma de expressar a idade do lodo é dada pela seguinte equação:

$$
\theta=\frac{\mathrm{VTA} * \mathrm{SSVTA}+\mathrm{VDEC} * \mathrm{SSVTA}}{\mathrm{QW} * \mathrm{SSVW}+\mathrm{QE} * \mathrm{SSVE}} \quad \text { (SPERLING, 1997) }
$$

Onde:

$\theta=$ idade do lodo

SSVTA = sólidos suspensos voláteis no tanque de aeração;

VTA = volume do tanque de aeração;

VDEC = volume do decantador secundário;

QW = vazão do excesso de lodo ativado;

SSVW = sólidos suspensos no excesso de lodo ativado;

SSVE = sólidos suspensos voláteis no efluente do decantador secundário;

$\mathrm{QE}=$ vazão na saída do decantador secundário.

Quando o teor de sólidos no efluente é pequeno, pode-se desprezar o termo "QE*SSVE" e a equação simplificada fica da seguinte forma (SPERLING, 1997):

$$
\theta=\frac{\operatorname{SSVTA}(\mathrm{VTA}+\mathrm{VDEC})}{\mathrm{QW} * \mathrm{SSVW}}
$$


- Decantabilidade do lodo

O grau de tratamento obtido num processo de aeração depende diretamente da decantabilidade do lodo ativado no decantador final. O floco biológico que se aglomera e decanta por gravidade permite um efluente claro. Ao contrário, partículas mal floculadas ou desenvolvimentos filamentosos que bóiam (que não se separam por gravidade), contribuem para o teor de DBO5 e sólidos em suspensão no efluente. $O$ excessivo transporte de floco, resultante da operação ineficiente, é denominado intumescimento do lodo. Isso pode ser causado por falta de nutrientes, presença de substâncias tóxicas ou sobrecarga. A decantabilidade do lodo biológico, em condições normais de operação depende da razão alimento/microorganismo.

\section{- $\quad$ Microscopia}

A forma dos organismos encontrados no tanque de aeração são usados, comumente, para indicar a eficiência e saúde de toda a estação. Existe uma grande quantidade de microorganismos que podem ser visualizados através de um microscópio. O crescimento e predominância de tipos de microorganismos são controlados por uma variedade de circunstâncias, incluindo o tipo de matéria/ alimento, relação metabólica e a quantidade de microorganismos.

\section{Controle operacional}

Para efetuarmos a retirada do lodo no decantador secundário podemos utilizar dois métodos:

- $\quad \mathrm{F} / \mathrm{M}$ constante

Deve-se controlar o SSVTA à medida que a DBO ou DQO diminuir ou aumentar. Esta relação deve ser mantida constante no controle do processo. Este método é mais difícil de ser utilizado na prática, pois necessita saber com antecedência a carga de DQO que terá o efluente bruto.

- Idade do lodo constante

A vantagem deste método esta na pouca utilização de analise laboratorial. Basta conhecer o volume do tanque de aeração, o volume do decantador final e valores dos SSVTA e SSVELA (sólidos suspensos voláteis no excesso de lodo).

\section{RESULTADOS E DISCUSSÃO}

O Quadro 2 apresenta os principais resultados encontrados no monitoramento analítico de uma estação de tratamento de esgoto por lodo ativado em fluxo contínuo, realizado durante o período de 17/07/06 a 09/05/07.

Os parâmetros analisados foram: $\mathrm{pH}, \mathrm{DBO}, \mathrm{DQO}$, Sólidos Sedimentáveis, Temperatura, OD, SSV, SST, N, P, Fenóis, Óleos e Graxas. Os pontos coletados foram: tanque pulmão, tanque de aeração, reciclo do lodo e saída do medidor. Os resultados visam demonstrar à efíciência do tratamento proposto e o atendimento a resolução do CONAMA 357 de 17 de março de 2005 art. 34, além das exigências existentes na Licença Ambienal de Operação da empresa. 
QUADRO 2 - Principais parâmetro resultantes do monitoramento analítico de uma estação de tratamento de esgoto por lodo ativado Chart 2 - Main parameters resulting from the analytical monitoring for the sewage treatment station using activated silt

\begin{tabular}{|c|c|c|c|c|c|c|c|c|c|c|c|c|c|}
\hline \multirow[b]{2}{*}{ Data } & \multirow[b]{2}{*}{ Local } & \multirow[b]{2}{*}{$\begin{array}{c}\text { PH } \\
-\end{array}$} & \multirow[b]{2}{*}{$\begin{array}{l}\text { DBO } \\
m g / l \mathrm{O}_{2}\end{array}$} & \multirow[b]{2}{*}{$\begin{array}{l}\text { DQO } \\
m g / l O_{2}\end{array}$} & \multirow[b]{2}{*}{$\begin{array}{l}\text { Sol.Sed } \\
m l / l / b\end{array}$} & \multirow[b]{2}{*}{$\begin{array}{l}\text { Temp. } \\
{ }^{\circ} \mathrm{C}\end{array}$} & \multicolumn{2}{|c|}{ Parâmetros } & \multirow[b]{2}{*}{$\begin{array}{l}\text { SST } \\
m g l L\end{array}$} & \multirow[b]{2}{*}{$\begin{array}{l}\mathrm{N} \\
m g / l\end{array}$} & \multirow[b]{2}{*}{$\begin{array}{l}\mathbf{P} \\
m g / l\end{array}$} & \multirow[b]{2}{*}{$\begin{array}{l}\text { Fenóis } \\
m g / L C_{6} H_{5} \\
\mathrm{OH}\end{array}$} & \multirow[b]{2}{*}{$\begin{array}{l}\text { O.G } \\
m g / l\end{array}$} \\
\hline & & & & & & & $\begin{array}{l}\text { OD } \\
m g / l O_{2}\end{array}$ & $\begin{array}{l}\mathrm{SSV} \\
m g / l\end{array}$ & & & & & \\
\hline \multirow[t]{5}{*}{$17 / 7 / 2006$} & Tanque Pulmão & 6,86 & 416 & 916 & 16 & 23,5 & - & - & - & 74,8 & 9,7 & 0,139 & 22 \\
\hline & Tanque Aeração & 7,38 & - & - & $>100,0$ & 24 & $7,2 / 7,1$ & $1.500,00$ & $2.233,00$ & - & - & - & - \\
\hline & Reciclo de Lodo & $*$ & $*$ & $*$ & $*$ & $*$ & $*$ & * & * & $*$ & $*$ & $*$ & $*$ \\
\hline & Saída (medidor Q) & 7,33 & 23 & 131 & 1,8 & 20 & - & - & - & * & $*$ & 0,002 & $<5,0$ \\
\hline & Eficiência \% & - & $94,40 \%$ & $85,60 \%$ & $88,70 \%$ & - & - & - & - & - & - & $98,50 \%$ & $77,20 \%$ \\
\hline \multirow[t]{5}{*}{$18 / 7 / 2006$} & Tanque Pulmão & 6,96 & 297 & 803 & 0,6 & 22,5 & & & & 81 & 9,45 & 0,142 & 48 \\
\hline & Tanque Aeração & 7,16 & - & - & $>100,0$ & 24 & $5,2 / 5,1$ & $1.433,00$ & 2.500 & - & - & - & - \\
\hline & Reciclo de Lodo & - & - & - & - & - & - & $1.533,00$ & 2.100 & - & - & - & - \\
\hline & Saída (medidor Q) & 7,23 & 10 & 89 & $<0,1$ & 23,5 & - & - & - & $*$ & * & $<0,001$ & $<5,0$ \\
\hline & Eficiência \% & - & $96,60 \%$ & $88,90 \%$ & $83,30 \%$ & - & - & - & - & - & - & $99,20 \%$ & $89,50 \%$ \\
\hline \multirow[t]{5}{*}{$19 / 7 / 2006$} & Tanque Pulmão & 7,58 & 350 & 615 & 0,1 & 23 & - & - & - & 83,4 & 9,08 & 0,083 & 53 \\
\hline & Tanque Aeração & 6,98 & - & - & $>100,0$ & 23,2 & $4,7 / 4,8$ & $1.733,00$ & $2.467,00$ & - & - & - & - \\
\hline & Reciclo de Lodo & - & - & - & - & - & - & $2.033,00$ & $2.900,00$ & - & - & - & - \\
\hline & Saída (medidor Q) & 7,08 & 6 & 79 & $<0,1$ & 22,5 & - & - & - & * & * & 0,002 & $<5,0$ \\
\hline & Eficiência \% & - & & - & & - & - & - & - & & & & \\
\hline \multirow[t]{5}{*}{$20 / 7 / 2006$} & Tanque Pulmão & 6,81 & 559 & $1.056,00$ & 0,7 & 26 & - & - & - & 107 & 6,74 & 0,096 & 65 \\
\hline & Tanque Aeração & 6,95 & - & - & $>100,0$ & 23,1 & $2,4 / 3,8$ & $1.800,00$ & $2.300,00$ & - & - & - & - \\
\hline & Reciclo de Lodo & - & - & - & - & - & - & $5.750,00$ & $8.550,00$ & - & - & - & - \\
\hline & Saída (medidor Q) & 7,18 & 15 & 92 & 0,1 & 22 & - & - & - & * & $*$ & 0,001 & $>5,0$ \\
\hline & Eficiência \% & - & $97,30 \%$ & $91,20 \%$ & $85,70 \%$ & - & - & - & - & & & $98,90 \%$ & $92,30 \%$ \\
\hline \multirow[t]{5}{*}{$21 / 7 / 2006$} & Tanque Pulmão & 5,28 & $1.347,00$ & $2.642,00$ & 0,5 & $*$ & - & - & - & 58 & 5,28 & 0,1 & 35 \\
\hline & Tanque Aeração & 7,1 & - & - & $>100,0$ & 24,9 & $2,4 / 0,7$ & $2.100,00$ & $2.667,00$ & - & - & - & - \\
\hline & Reciclo de Lodo & - & - & - & - & - & - & $6.950,00$ & $10.450,00$ & - & - & - & - \\
\hline & Saída (medidor Q) & 7,17 & 20 & 103 & 0,1 & 24 & - & - & - & $*$ & $*$ & $>0,001$ & $>5,0$ \\
\hline & Eficiência \% & - & $98,50 \%$ & $96,10 \%$ & $80 \%$ & - & - & - & - & - & - & $99,00 \%$ & $85,70 \%$ \\
\hline
\end{tabular}




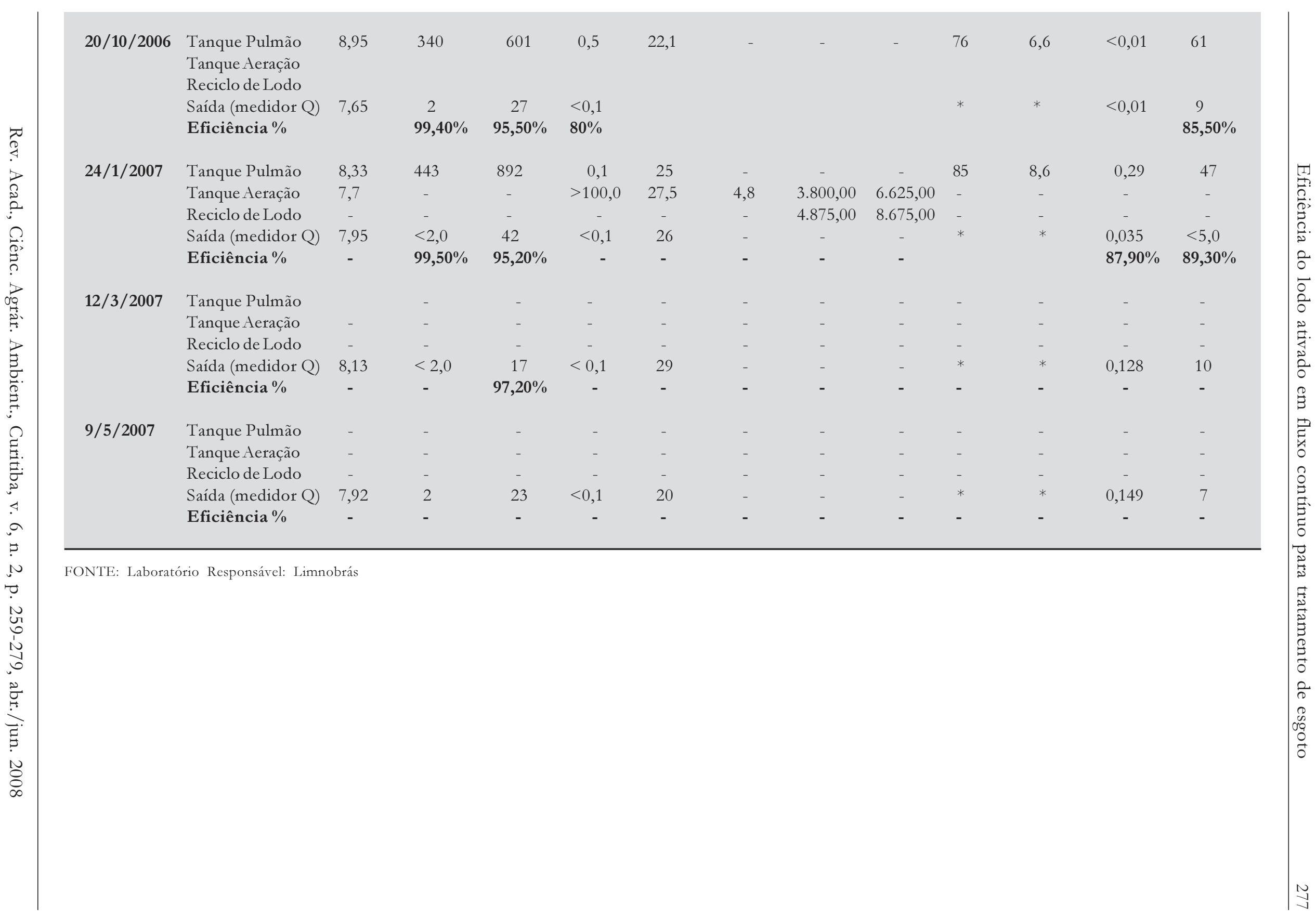


Conforme monitoramento analítico descrito no quadro 2, observa-se que o tratamento proposto por lodo ativado tem uma eficiência acima de 95\%. A DBO5 final atingida apresentou valores em torno de 02 - $23 \mathrm{mg} / \mathrm{l}$, resultando uma média em torno de $9,1 \mathrm{mg} / 1$, enquanto que o limite exigido pelo órgão ambiental é de $50 \mathrm{mg} / \mathrm{l}$. Já a DQO final atingida apresentou valores em torno de 17 - 131 $\mathrm{mg} / \mathrm{l}$, resultando uma média em torno de $67 \mathrm{mg} / \mathrm{l}$, enquanto que o limite exigido pelo órgão ambiental é de $125 \mathrm{mg} / \mathrm{l}$. Estes resultados deixam claro que o tratamento biológico por lodo ativado é a melhor alternativa para o tratamento do esgoto em fluxo contínuo (Figura 12).

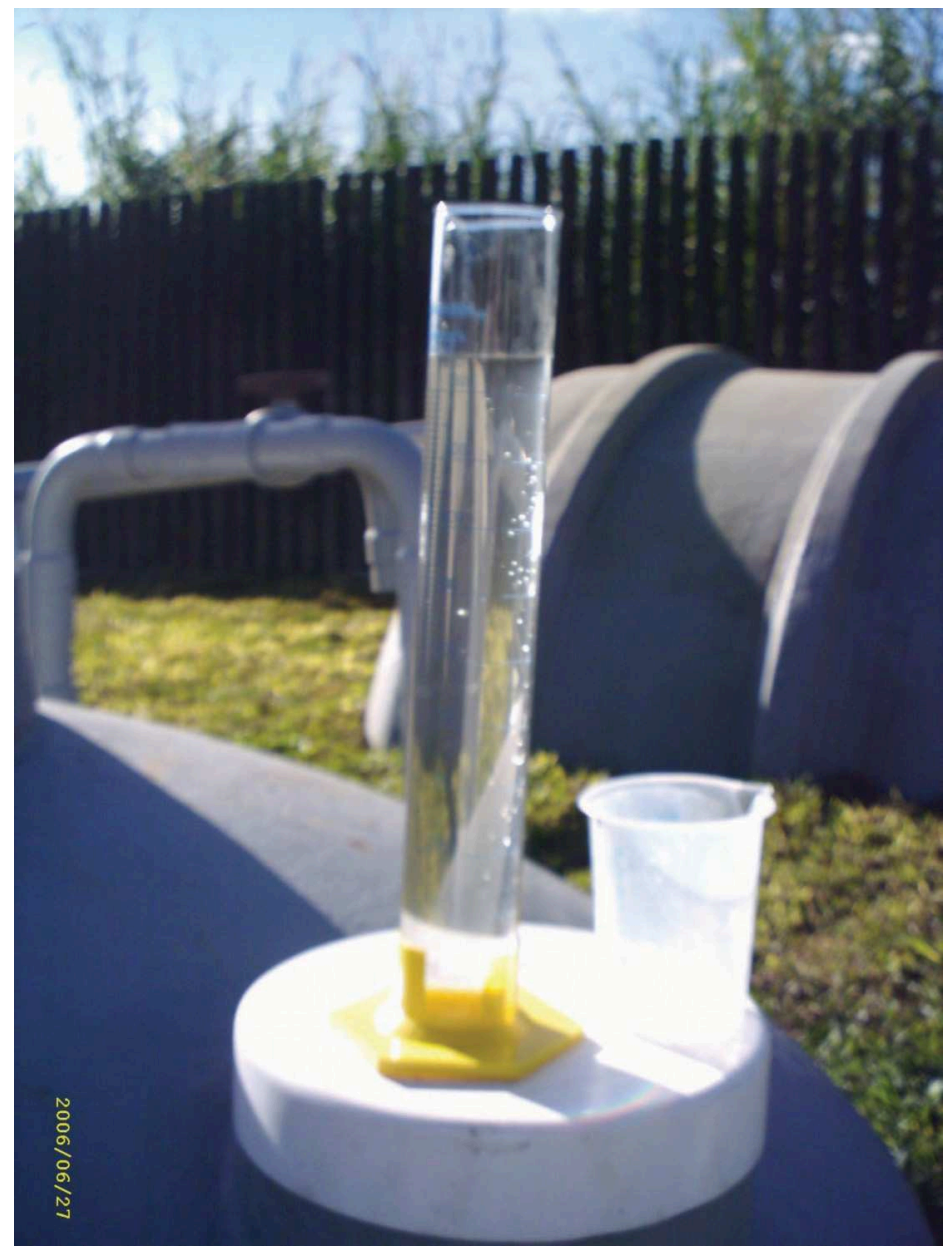

FIGURA 12 - Efluente tratado

Figure 12 - Treated effluent

\section{CONCLUSÕES}

O processo biológico por lodo ativado apresenta-se como altamente eficiente, principalmente na remoção de $\mathrm{DBO} / \mathrm{DQO}$ e com baixo custo. Sua performance justifica-se pelo fato de parte da matéria orgânica ser mineralizada para gás carbônico e água, parte ser convertida em biomassa bacteriana, que pode ser reutilizada no próprio sistema, o que representa uma grande economia. Além disso, na indústria, o efluente tratado pode ser reutilizado no processo industrial, uma vez que nesta empresa a captação de água é feita através de poço artesiano, o que credencia o sistema de lodo ativado a ter uma relação custo beneficio muito favorável. A alta eficiência, acima de $95 \%$, e o baixo custo do tratamento por lodo ativado são mais evidentes quando se observa que, atualmente, este é o sistema de tratamento mais usado na depuração de efluentes sanitários. 


\section{REFERENCIAS}

CLESCERI, L. S.; GREENBERG, A. E.; EATON, A. D. (Ed.). Standard methods for the examination of water and wastewater. 20th ed. Washington, DC: American Public Health Association, 1998.

JORDÃO, E. P. Tratamento de esgotos domésticos. Rio de Janeiro: ABES, 1998.

HAMMER, M. J.; HAMMER Jr., M. J. Water and wastewater technology. 3rd ed. New Jersey: Prentice Hall, 1996.

QASIM, S. R. Wastewater treatment plants: planning, design, and operation. New York: CBS College, 1985.

METCALF, E. Wastewater engineering: treatment, disposal and reuse. 3 ed. Nova York: McGraw Hill, 1991.

PESSOA, C.; JORDÃO, E. P. Tratamento de esgotos domésticos. 3rd ed. Rio de Janeiro: ABES, 1995. SPERLING, V. M. Princípios do tratamento biológico de águas residuárias: lodos ativados. Belo Horizonte: DESA/UFMG, 1997. v. 4.

Princípios do tratamento biológico de águas residuárias: princípios básico do tratamento de esgotos. Belo Horizonte: DESA/UFMG, 1996. v. 2.

VIESSMAN Jr., W.; HAMMER, M. J. Water supply and pollution control. 4th ed. New York: Harper \& Row, 1985. 